\title{
THE PROBLEM OF THE INDETERMINATE DEFENDANT IN TORT LAW IN EUROPE
}

\begin{abstract}
The article discusses the problem of the indeterminate defendant in European tort law systems and in the projects aiming to unify tort law in Europe, such as Draft Common Frame of Reference and Principles of European Tort Law.

The given issue relates to a situation where there is a damage caused by one factor, yet upon available evidence one may indicate a few potential factors which might have led to the damage, but it cannot be ascertained which factor was the actual cause of it. The problem is addressed with reference to two scenarios. First, when there is a limited and known number of persons acting tortiously, each of whom potentially might have led to the damage, but only one of them had actually caused it. Second, when it is certain that one tortfeasor from the undetermined group of tortfeasors caused damage to some of the injured persons from the group of the injured persons, but it cannot be established precisely which tortfeasor caused damage to precisely which injured person.

In comparative law analysis, one may find various attempts to deal with the given issue, which come from the balance of ratios given to different solutions, as well as the legal possibilities or obstacles in national tort law systems. The main possibilities are: all-or-nothing approach, joint and several liability, and proportional liability. Those solutions are discussed in article in more detail with conclusion that the bold proposition of proportional liability presented in Principles of European Tort Law seems to be the most appropriate.
\end{abstract}

\section{Keywords}

tort law - alternative causation - indeterminate defendant - joint and several liability proportional liability

* Katarzyna Krupa-Lipińska, Juris doctor (PhD), Assistant at the Chair of Civil and International Trade Law, Faculty of Law and Administration, Nicolaus Copernicus University in Torun, Poland; Patent and Trade Mark Attorney. E-mail: kkrupa@umk.pl. 
Professors G. Calabresi and J.H. King once started their articles by noticing that those who are dealing with tort law will always, sooner or later, turn their thoughts to causation ${ }^{1}$. Causation is indeed the essence of civil liability or - paraphrasing philosophers ${ }^{2}$ - its cement. The first (or - according to some legal systems - the only) element of causal inquiry is the conditio sine qua non test, which in common law countries is called rather the but-for test. The test is made by asking whether the result would have happened, if the factor in question had not happened (in other words: but for the inquired factor). At first glance it might seem that the application of this test is relatively simple. The situation becomes complicated, however, when the causal relation is uncertain. There are a few issues that relate to uncertainty of causation, among which the problem of alternative causation $^{3}$ (and within it - the problem of the indeterminate defendant) is one of the most important and controversial.

In general, the problem of the indeterminate defendant relates to a situation where there is indivisible damage caused by one factor, yet upon available evidence one may indicate a few potential factors which might have led to the damage and it cannot be ascertained which factor actually caused $i^{4}$. The essence of the issue seems to be rather evidentiary (i.e. relating to procedural law) than concerning material law, but because of its inherent problem of the impossibility of proving the causal relation, it is commonly recognised as an issue of material law. There are a few issues in material civil law where the given problem is discussed, namely causation 5 , plurality of tortfeasors, and burden and standard of proof ${ }^{6}$. In this article the problem will be addressed from the causal point of view.

\footnotetext{
1 G. Calabresi, Concerning Cause and the Law of Torts: An Essay for Harry Kalven, Jr, University of Chicago Law Review 1975, vol. 43, no. 1, p. 69; J.H. King, Jr, Causation, Valuation and Chance in Personal Injury Torts Involving Preexisting Conditions and Future Consequences, Yale Law Journal 1981, vol. 90, no. 6, p. 1353 (with reference to article of G. Calabresi).

2 See: J.L. Mackie, The Cement of the Universe: A Study of Causation, Oxford 1980.

3 "Alternative causation" is sometimes also called "potential causation".

4 See: M. Infantino, E. Zervogianni (eds), Causation in European Tort Law, on file with the author, Cambridge University Press, forthcoming 2017.

5 See: B. Winiger, H. Koziol, B.A. Koch, R. Zimmermann (eds), Digest of European Tort Law, Vol. 1: Essential Cases on Natural Causation, Wien-New York 2007, pp. 353-455; E. Bagińska, Odpowiedzialność deliktowa w razie niepewności związku przyczynowego. Studium prawnoporównawcze [Tort Liability under Uncerainty and Complexity of Causation. A Comparative Law Study], Torun 2013, pp. 113-228.
} 


\section{SCENARIOS OF THE PROBLEM OF THE INDETERMINATE DEFENDANT}

In modern comparative law projects 7 , the alternative causation issue is discussed with reference to various causal scenarios. The number of those scenarios differs. However one might distinguish between those which relate to uncertainty as to a defendant, and those relating to uncertainty as to an injured person. Another possible division is whether the group of potential causes is composed purely of tortfeasors, or whether there is also a factor for which no one bears liability (eg. natural event, non-tortious behaviour, or behaviour of a plaintiff). Scenarios might also be divided by the number of injured persons. Regardless of the many ways in which that hypothesis might be divided, in this article just two of them will be discussed. The analysis will not refer to cases where an alternative factor was of a kind for which no one bears liability, for example a natural event or events within the victim's sphere. The discussion will also not refer to a scenario where the identities of all of the tortfeasors of an indivisible damage are known, but factual uncertainty relates to the extent of harm that may be attributed to each of them.

1.1. The first (classical) scenario concerning uncertainty as to a cause is that there is a limited and known number of persons acting tortiously, each of whom potentially might have led to indivisible damage, but only one of them had actually caused it. A typical example (coming from old Austrian $^{8}$, French ${ }^{9}$ and US judgments ${ }^{10}$ ) is a hunting case: two hunters shooting in the same direction from the same-type weapon, but only one bullet hits the injured person. It cannot be ascertained from which weapon the bullet actually came. Relying on classical procedural rules, the plaintiff's claim should be rejected, because he/she cannot establish who actually caused the damage, i.e. who is the actual tortfeasor, although the

See: S. Steel, Proof of Causation in Tort Law, Cambridge 2015, p. 139 et seq.

See: Winiger, Koziol, Koch, Zimmermann (eds), supra note 5; J. Spier (ed.), Unification of Tort Law: Causation, The Hague-London-Boston 2000; Infantino, Zervogianni, supra note 4.

$8 \quad$ E.g. Oberster Gerichtshof, 23.12.1908, Rv VI 308/8, JB1 1909, 81; Oberster Gerichtshof, 23.05.1916, Rv II 314/16, JB1 1916, 477.

$9 \quad 2^{\text {nd }}$ Civil Chamber of the Cour de Cassation, 13.03.1975, Bull. Civ. II, no. 88.

10 Oliver v. Miles [1927] 144 Miss. 852, 110 So. 666, 50 A.L.R. 357. 
plaintiff is able to sue all of the potential tortfeasors (who acted tortiously and who commonly created the risk of damage) and prove the damage.

1.2. The second scenario extends the number of injured persons. It is certain that one tortfeasor from the undetermined group of tortfeasors caused damage to some of the injured persons from the group of the injured persons, but it cannot be established precisely which tortfeasor caused damage to precisely which injured person. From the tortfeasor(s) point of view it is certain that he/she caused damage, but it is uncertain to which injured person (uncertainty on the side of the injured person). On the other hand, from the point of view of the injured person(s), it is certain that the damage was caused by one tortfeasor, but he/she cannot establish by which one (uncertainty on the side of a cause). An example that triggered the given scenario comes from a famous DES cases ${ }^{11}$ : a pregnant women were taking medicines that included an ingredient DES (diethylstilbestrol). Medicines with DES were produced by many different pharmaceutical companies and were allowed in USA. Some of the girlchildren of those women (second generation) became sick with a cancer because of the DES. From a general point of view, it was certain that the medicine produced by many pharmaceutical companies caused cancer to many injured persons, however in each individual case it was impossible to prove that the plaintiff's cancer was caused by medicine from a particular pharmaceutical company. It might be seen that from general point of view the scenario does not create the problem of alternative causation, because it is clear that each pharmaceutical company certainly caused damage. However, from an individual plaintiff's point of view, the hypothesis is an alternative causation problem, for she cannot prove which tortfeasor from the group of tortfeasors caused her damage. From individual point of view this scenario is then similar to the first scenario, except that the number of potential tortfeasors is - as a rule undetermined.

11 See: Sindell v. Abbot Labs, 607 P.2d 924 (1980). 


\section{Possible SOlutions to the PROBLEM OF ALTERNATIVE CAUSATION}

As outlined at the outset, a commonly recognised prerequisite of liability is a causal link between a certain event and damage. The essence of an issue of alternative causation is that it does not fulfil the test of conditio sine qua non, or more precisely - it is uncertain whether between the tortfeasor's actions or omissions and the damage this test is passed ${ }^{12}$. Since the burden of proof of causation lies on the plaintiff, he/she needs to undermine the defendant's claim that without his/her conduct the damage would have happened, because another (alternative) event would have caused it. If the plaintiff is not able to prove the causation between defendant's acts and damage, the later is relieved from liability. This outcome, however, does not always seem to be fair and just, and therefore, in comparative law analysis, one may find various attempts to deal with this problem. The differences between legal systems or the doctrinal disputes within them are so significant, that some authors humorously refer to the problem as "the jungle of alternative causation"13, which is actually quite true. Those differences come from the balance of ratios given to different solutions, as well as the legal possibilities or obstacles in certain tort law systems. Different approaches were also taken by two main projects on the unification of tort law, namely by the Principles of European Tort Law (PETL) ${ }^{14}$ and Draft Common Frame of Reference $(\mathrm{DCFR})^{15}$. The main possibilities are: an all-or-nothing approach, joint and several liability, and proportional liability. All of them will be discussed further in more detail.

\footnotetext{
12 See: Winiger, Koziol, Koch, Zimmermann (eds), supra note 5, p. 4.

13 Infantino, Zervogianni, supra note 4.

14 Project prepared by the European Group on Tort Law - see: European Group on Tort Law, Principles of European Tort Law. Text and Commentary, Wien 2005.

15 Project prepared by Study Group on a European Civil Code and the Research Group on EC Private Law (Acquis Group) - see Ch. von Bar, E. Clive, H. Schulte-Nölke, Principles, Definitions and model Rules of European Private Law. Draft Common Frame of Reference (DCFR), Munich 2009.
} 


\subsection{ALL-OR-NOTHING APPROACH}

The all-or-nothing approach is a result of a strict interpretation of the conditio sine qua non requirement. Case-law and doctrine in some European countries support this view. It is, then, crucial to establish a causal relation between the individually recognised tortfeasor and the damage and hold him/her liable in full16. Taking into account that the essence of problem of alternative causation is inherent evidentiary problems in establishing which tortfeasor actually caused the damage, some jurisdictions in which the all-or-nothing approach is accepted are using certain ways to overcome those difficulties for the plaintiff's benefit. For example, in Belgium the court may be willing to find upon circumstances of the case that the damage was actually the result of the activity of one of defendants (his/her act was the actual cause of damage) and hold him/her liable ${ }^{17}$. In some jurisdictions facilitation for the plaintiff's claim follows from the proper establishment of the standard of proof or burden of proof. In English ${ }^{18}$ and Danish law the applicable standard of proof is the preponderance of evidence, which means that the requirement of causation is met if it is more probable than not (more than 50\%) that the defendant caused the damage. A similar approach is taken by Italian law, which applies the "theory of the most probable cause".

\subsection{JOINT AND SEVERAL LIABILITY}

In Book VI - 4:103 of Draft Common Frame of Reference the rebuttable presumption of causing damage in the case of alternative causes is prescribed. The article reads as follows: "Where legally relevant damage may have been caused by any one or more of a number of occurrences for which different persons are accountable and it is established that the damage was caused by one of these occurrences but not which one, each person who is accountable for any of the occurrences is rebuttably

\footnotetext{
16 See: Infantino, Zervogianni, supra note 4.

17 See: Court of Appeal of Brussels, 23.12.1927, RGAR 1928, no. 227.

18 Solution to the problem of alternative causation in England is one of the most complicated ones. Depending on a case, it may be also proportional liability or joint and several liability (see below).
} 
presumed to have caused that damage" and according to Article VI - 6:105 "Where several persons are liable for the same legally relevant damage, they are liable solidarily". This approach is common to certain jurisdictions, where cases of alternative causation are solved by imputing joint and several liability on all potential tortfeasors. It is made either by a statutory provision, case-law ${ }^{19}$, or is reflected in doctrinal opinions.

In cases where all potential tortfeasors are known (scenario 1.1.) statutory provisions, for example in Germany, the Netherlands, Greece and Ireland in general impose joint and several liability. The statutory provision in England that imposes joint and several liability relates to the specific type of cases (mesothelioma disease).

German BGB in § 830(1)2 stipulates, "if several persons (mehrere) have caused injury through a jointly undertaken delict, each person is liable for the injury. The same applies where it cannot be established which of several participants (Beteiligten) has caused the injury by his act"20. Upon $\S 840$ BGB the liability of alternative tortfeasors is joint and several. The number of conditions for application of $\S 830(1) 2$ BGB differ in jurisdiction and doctrine ${ }^{21}$. S. Steel points to six of them:

1. "It must be the case that more than one person has acted, each person independently of the other, in such a way that each person's conduct increases the risk of injury to the claimant.

2. Either (a) the risk-increasing conduct of only one such person was a cause of the claimant's injury or (b) the risk-increasing conduct of some such persons caused the claimant's damage.

3. Each person's conduct may have caused the entirety of the claimant's damage.

4. Either (a) it is not possible to determine which person(s) caused the damage or $(b)$ it is not possible to determine the extent of the damage caused by each person.

\footnotetext{
19 See: Infantino, Zervogianni, supra note 4.

20 Translation by Steel, supra note 6, p. 141. In original: "Haben mehrere durch eine gemeinschaftlich begangene unerlaubte Handlung einen Schaden verursacht, so ist jeder für den Schaden verantwortlich. Das Gleiche gilt, wenn sich nicht ermitteln lässt, wer von mehreren Beteiligten den Schaden durch seine Handlung verursacht hat".

21 Compare: Bundesgerichtshof, 22.06.1976, VI ZR 100/75.
} 
5. Apart from proof of natural causation, the claimant has satisfied the other conditions of a cause of action against each person.

6. The claimant must not be able to establish that any individual person, against whom it seeks to rely upon § 830 I 2 BGB, was a wrongful cause of its injury"22.

Similarly Article 6:99 of the Dutch Civil Code states that "Where the damage is caused by two or more events, for each of which another person is liable, and it is ascertained that the damage originates from at least one of these events, then each of these liable persons is joint and several liable for that damage, unless a liable person proves that this specific damage is not caused by the event for which he himself is liable" 23 . Also Article 926 sent. 2 of Greek Civil Code stipulates that "if damage is provoked by two or several authors and it cannot be ascertained which author's action did in fact lead to the damage, all of them are held jointly liable"24. This provision stipulates the presumption that the act of a possible tortfeasor is causally linked with the damage. The presumption is rebuttable, which in consequence leads to the reversing of the burden of proof ${ }^{25}$. E. Dacoronia points to the following requirements for applicability of the given article:

1. "Acts of more than one person. It is of no interest whether the acts were simultaneous or successive; if they were alike or not; if they were based on a prior agreement between the wrongdoers or not.

2. Each one of the several persons' act is required to be independently adequate to have caused the damage, i.e. is required to be regarded as a potential cause of the wrong complained of. Should one of the two or more possible tortfeasors prove the lack of adequate causation between his act and the damage, he is excluded from liability.

\footnotetext{
22 Steel, supra note 6, pp. 142-143.

23 English translation of the Dutch Civil Code available at http://www.dutchcivillaw.com/ legislation/dcctitle6611bb.htm [last accessed: 2.11.2016].

24 Provision of Article 926 sent. 2 as referred in: E. Dacoronia, Greece, [in:] B. Winiger, H. Koziol, B.A. Koch, R. Zimmermann (eds), Digest of European Tort Law, Vol. 1: Essential Cases on Natural Causation, Wien-New York 2007, p. 362.

25 Ibidem, p. 363.
} 
3. Each one of the several persons' act is required to be tortious based on fault i.e. it would give rise to liability could causation be proven. However, it is accepted that Article 926 GCC applies by analogy to strict liability also.

4. It must be impossible to ascertain which particular action did in fact lead to the damage or the extent to which the damage was caused by each one of the tortfeasors" 26 .

Irish law takes in that regard a slightly different approach, by deeming tortfeasors concurrent wrongdoers. Sec. 11(3) of the Civil Liability Act 1961 reads as follows: "Where two or more persons are at fault and one or more of them is or are responsible for damage while the other or others is or are free from causal responsibility, but it is not possible to establish which is the case, such two or more persons shall be deemed to be concurrent wrongdoers in respect of the damage". Concurrent wrongdoers are defined in sec. 11(1) of the Act of 1961 as "two or more persons (...) when both or all are wrongdoers and are responsible to a third person (in this Part called the injured person or the plaintiff) for the same damage, whether or not judgment has been recovered against some or all of them". According to sec. 12(1) of the Act 1961 "concurrent wrongdoers are each liable for the whole of the damage in respect of which they are concurrent wrongdoers".

In England joint and several liability in an alternative causation context is established in legislation for a specific type of cases. Sec. 3 of the Compensation Act 2006 relates to mesothelioma work-related diseases. It is important to notice, that mesothelioma is a cancer usually caused by exposure to asbestos and even a single asbestos fibre might cause it. Due to the fact that mesothelioma symptoms may not appear until 30-50 years after asbestos exposure (leading to death in approx. 14 months) if the employee worked for a few employers who exposed him/her to asbestos, it is impossible to prove in which period of time the employee contracted the disease and in consequence - which employer should be held liable. It is then the typical case of alternative causation. In that regard, according sec. 3(1) of 2006 Act:

26 Ibidem, p. 363 and references to Greek literature thereof. 
1. a person ("the responsible person") has negligently or in breach of statutory duty caused or permitted another person ("the victim") to be exposed to asbestos,

2. the victim has contracted mesothelioma as a result of exposure to asbestos,

3. because of the nature of mesothelioma and the state of medical science, it is not possible to determine with certainty whether it was the exposure mentioned in paragraph (a) or another exposure which caused the victim to become ill, and

4. the responsible person is liable in tort, by virtue of the exposure mentioned in paragraph (a), in connection with damage caused to the victim by the disease (whether by reason of having materially increased a risk or for any other reason).

According to sec. 3(2)(b) the responsible person shell be held liable jointly and severally with any other responsible person.

The abovementioned (revised ${ }^{27}$ ) sec. 3 Compensation Act 2006 was a legislative reaction to a judicial decisions concerning mesothelioma disease, which started from the famous Fairchild v. Glenhaven Funeral Services Ltd [2002] ${ }^{28}$ and more importantly Barker v. Corus UK Ltd [2006] ${ }^{29}$ which established the proportional liability of employers in mesothelioma cases. It is however worth noticing, that the applicability of this section is restricted only to mesothelioma cases ${ }^{30}$ and in a recent judgment of the UK Supreme Court in International Energy Group Ltd v. Zurich Insurance Plc UK [2015] $]^{31}$ it was explained that Compensation Act 2006 does not apply to certain jurisdictions (in this case: to Guernsey) then Barker remains a good law32. As their Lordships said "the Act left the common law intact but carved an exception out of it for mesothelioma" 33 and that the

\footnotetext{
27 Sec. 3 Compensation Act 2006 has been changed by Contribution for Mesothelioma Claims Regulations 2006, Statutory Instrument 2006/3259.

28 UKHL 22; [2003] 1 A.C. 32 (HL).

29 UKHL 20; [2006] 2 A.C. 572 (HL).

30 See: K. Oliphant, England, [in:] H. Koziol, B.C. Steininger (eds), European Tort Law 2006, Wien 2008, p. 154.

$31 \quad$ UKSC 33; [2015] 2 W.L.R. 1471 (SC).

32 See: J. Morgan, Reinterpreting the Reinterpretation of the Reinterpretation of Fairchild, Cambridge Law Journal 2015, vol. 74, no. 3, p. 397.

33 Lord Sumption in International Energy Group Ltd v. Zurich Insurance Plc UK [2015] UKSC 33; [2015] 2 W.L.R. 1471 (SC), para. 179.
} 
“2006 Act was clearly passed to change a common law rule expounded in Barker (...). The United Kingdom Parliament's reaction was its right, but does not alter the common law position apart from the statute, or have any necessary effect in jurisdictions where the common law position has not been statutorily modified" 34 .

Joint and several liability is established by case-law, for example in Austria, France and Poland ${ }^{35}$. In Austria it is done by the adoption of the concept that all individual actions created a single (combined) act. It is explained by stating that all the tortfeasors acted wrongfully and negligently, jointly creating a risky behaviour ${ }^{36}$. This joint behaviour constitutes therefore a conditio sine qua non of the damage and the defendants are jointly liable in analogy to $\S 1302$ ABGB, unless the tortfeasor can prove that his/her behaviour was not the cause of the damage (reversed burden of proof) $)^{37}$.

34 Lord Mance in International Energy Group Ltd v. Zurich Insurance Plc UK [2015] UKSC 33; [2015] 2 W.L.R. 1471 (SC), para. 27.

35 See: case SN [Supreme Court] of 18.01.2012, I CSK 157/11, OSNC ZD 2013, item 30 discussed in: E. Bagińska, I. Adrych-Brzezińska, Poland, [in:] E. Karner, B.C. Steininger (eds), European Tort Law 2013, Berlin/Boston 2014, pp. 497-499; Joint and several liability is also strongly supported by Polish doctrine - see: B. Lewaszkiewicz-Petrykowska, Wyrzadzenie szkody przez kilka osób [Cause of Damage by Several Persons], Warszawa 1978, pp. 75-78; T. Dybowski, System Prawa Cywilnego [The System of Civil Law], Wrocław-WarszawaKraków-Gdańsk 1976, p. 264. In contrary (advocating for all-or-nothing approach) see: M. Kaliński, System Prawa Prywatnego. Prawo zobowiazań - część ogólna. Tom 6 [Private Law System. Obligation Law - General Part. Vol. 6], Warszawa 2012, pp. 137-138.

36 See: Oberster Gerichtshof, 23.12.1908, Rv VI 308/8, JB1 1909, 81; Oberster Gerichtshof, 23.05.1916, Rv II 314/16, JB1 1916, 477. It does not apply, however, when the causal connection between behaviour of one tortfeasor and entire damage is established and the causal connection between a second tortfeasor is uncertain - Oberster Gerichtshof, 22.04.1986, 2 Ob. 12/86, JB1 1986, 787 - cases reference and commentary by B.A. Koch, Austria, [in:] B. Winiger, H. Koziol, B.A. Koch, R. Zimmermann (eds), Digest of European Tort Law, Vol. 1: Essential Cases on Natural Causation, Wien-New York 2007, pp. 359-361.

$37 \S 1302$ ABGB stipulates for joint and several liability of tortfeasors who contributed to the harm. In original: „In einem solchen Falle verantwortet, wenn die Beschädigung in einem Versehen gegründet ist, und die Antheile sich bestimmen lassen, jeder nur den durch sein Versehen verursachten Schaden. Wenn aber der Schade vorsätzlich zugefügt worden ist; oder, wenn die Antheile der Einzelnen an der Beschädigung sich nicht bestimmen lassen, so haften Alle für Einen, und Einer für Alle; doch bleibt demjenigen, welcher den Schaden ersetzt hat, der Rückersatz gegen die Uebrigen vorbehalten". 
In France the courts apply two different theories to hold defendants jointly and severally liable in cases of alternative causation ${ }^{38}$. The first is "collective custody" (garde collective/garde en commun)39. It is based on Article 1384 of French Civil Code which stipulates liability for things in one's care (responsabilité $d u$ fait des choses). Referring to hunting cases, the court considers that a tortfeasor's weapons produced a "single spray of bullets" of which hunters had "collective custody". "In cases where each defendant's act is connected with and inseparable from those committed by the other member(s) of the group, and it appears impossible to determine who exactly was the custodian (gardien) of the object(s) concerned, the courts have tended to categorise both (or all) of the defendants as gardiens and find them liable in solidum" 40 . If there is a geographical proximity between potential causes and damage then it creates a rebuttable presumption of custody for each defendant and the rebuttable presumption of causation. This presumption is held against each defendant, as if he/she was the sole custodian ${ }^{41}$.

The second theory in the French jurisdiction is based on Article 1382 or 1383 of the French Civil Code which stipulates liability for one's own actions (responsabilité $d u$ fait personnel) and the concept of joint action (action commune). Among others, it applies in cases of a gang's crimes ${ }^{42}$ and for admission there needs to be established a presumption of intention (presumption of shared will - volonté commune) and a rebuttable presumption of causation (that the tortfeasor participated - also indirectly in an act that led to the damage ${ }^{43}$. Similar attempts to solve the problem of alternative causation are sometimes seen in the Belgian jurisdiction. In the case where four boys were playing by throwing small stones to each other and where one of those stones hit the eye of a young boy (who was not taking part in this game) the court redefined the cause of damage by stating that the essential cause (la cause essentielle) was not an individual

\footnotetext{
38 See: O. Moréteau, C. Pellerin-Rugliano, France, [in:] B. Winiger, H. Koziol, B.A. Koch, R. Zimmermann (eds), Digest of European Tort Law, Vol. 1: Essential Cases on Natural Causation, Wien-New York 2007, p. 364.

39 E.g. $2^{\text {nd }}$ Civil Chamber of the Cour de Cassation, 13.03.1975, Bull.Civ. II, no. 88.

40 Moréteau, Pellerin-Rugliano, supra note 38, p. 365 and literature cited thereof.

41 Ibidem, pp. 364-365 and literature cited thereof.

42 See e.g.: $2^{\text {nd }}$ Civil Camber of the Cour de Cassation, 2.04.1997, Bull.Civ.II, no. 112.

43 See: Moréteau, Pellerin-Rugliano, supra note 38, pp. 366-367 and literature cited thereof.
} 
act of throwing stones, but the participation of all four boys in a dangerous game and held the boys and their parents jointly liable ${ }^{44}$. I. Durant rightly noticed, that this way of reasoning by the court is in fact a circumvention of the problem by a redefinition of misbehaviour ${ }^{45}$. It gives also a possibility of overcoming a requirement of "common fault" which includes a specific intentional element, which is sometimes used in cases of multiple tortfeasors ${ }^{46}$.

When it comes to the application of joint and several liability in scenario 1.2. the results in various legal systems differ ${ }^{47}$. It is excluded then in Germany, for $\S 830(1) 2$ is interpreted narrowly. It is explained either by stating that the plaintiff cannot prove that a concrete defendant actually exposed him to a "concrete danger" 48 or by saying that $\S 830(1) 2$ applies if each defendant potentially caused the entire loss49 or - to put it differently - that it reflects "the individualistic approach (...), which does not take account of the "multi-dimensional» character of the loss in its totality" 50 . On the other hand, the DES daughters case (and similar environmental and riot cases ${ }^{51}$ ) succeed in the Netherlands relying upon Article 6:99 of Dutch Civil Code holding any manufacturer liable in full to the plaintiff52.

The main arguments used to justify the imposition of joint and several liability in scenario 1.1 are that: a) it alleviates the plaintiff's difficulties (which are often impossible to overcome) in proving which tortfeasor

\footnotetext{
44 The case referred by I. Durant; idem, Belgium, [in:] B. Winiger, H. Koziol, B.A. Koch, R. Zimmermann (eds), Digest of European Tort Law, Vol. 1: Essential Cases on Natural Causation, Wien-New York 2007, p. 369.

45 Ibidem, p. 369.

46 Ibidem.

47 See: Infantino, Zervogianni, supra note 4.

48 Ibidem.

49 See: OLG Neustadt, 20.12.1957, 2 U 135/57 referred in R. Zimmermann, J. Kleinschmidt, Germany, [in:] B. Winiger, H. Koziol, B.A. Koch, R. Zimmermann (eds), Digest of European Tort Law, Vol. 1: Essential Cases on Natural Causation, Wien-New York 2007, p. 448.

50 See: ibidem, p. 448 and literature quoted thereof.

51 See: W.H. van Boom, I. Giesen, Netherlands, [in:] B. Winiger, H. Koziol, B.A. Koch, R. Zimmermann (eds), Digest of European Tort Law, Vol. 1: Essential Cases on Natural Causation, Wien-New York 2007 p. 370 . Enviromental case (contaminating water) is: Moerman/Bakker, HR 17.01.1997, NJ 1997, 230. Riot case (arson by different groups of hooligans) is: HR 31.01.2003, NJ 2003, 346.
}

$52 \quad$ Hoge Raad, 9.10.1992, NJ 1994, 535. 
actually caused the loss53; b) it would be inequitable (unfair) to leave the injured person without compensation in cases where he/she undoubtedly has a claim against one of the actors ${ }^{54}$ (equity argument); c) liability for the risk creation: all the wrongdoers commonly created a risky behaviour, which resulted in damage ${ }^{55}$. Therefore it would be fair to hold those actors jointly and severally liable, for the difficulty in proof comes from their own sphere and the risk of damage has been created by each of them ${ }^{56}$ (liability for the creation of risk).

On the other hand the restriction in imposition of joint and several liability in scenario 1.2. is explained by saying that joint and several liability "would lead to the absurd consequence that a potential tortfeasor may be liable for a multiple of the loss which he has possibly caused" 57 .

\subsection{Proportional LIABILITY}

Proportional liability in the context of alternative causation is proposed in Article 3:103 of Principles of European Tort Law, which states that: "(1) In case of multiple activities, where each of them alone would have been sufficient to cause the damage, but it remains uncertain which one in fact caused it, each activity is regarded as a cause to the extent corresponding to the likelihood that it may have caused the victim's damage. (2) If, in case of multiple victims, it remains uncertain whether a particular victim's damage has been caused by an activity, while it is likely that it did not cause the damage of all victims, the activity is regarded as a cause of the damage suffered by all victims in proportion to the likelihood that it may have caused the damage of a particular

\footnotetext{
53 See: Austrian Oberster Gerichtshof, 22.04.1986, 2 Ob. 12/86, JB1 1986,787; the reasoning behind the Greek legislation - see: Dacoronia, supra note 24, p. 363.

54 See: in German law: Bundesgerichtshof, 22.06.1976, VI ZR 100/75; in Greek law: Dacoronia, supra note 24, p. 363 and literature cited therof; in Ireland: E. Quill, Ireland, [in:] B. Winiger, H. Koziol, B.A. Koch, R. Zimmermann (eds), Digest of European Tort Law, Vol. 1: Essential Cases on Natural Causation, Wien-New York 2007, p. 380, footnote 107.

55 See: Austrian Oberster Gerichtshof, 23.12.1908, Rv VI 308/8, JB1 1909, 81; Oberster Gerichtshof, 23.05.1916, Rv I 314/16, JB1 1916, 477; Belgian case of boys who threw small stones - presented by Durant, supra note 44, p. 369.

56 Dacoronia, supra note 24, p. 363 and literature cited thereof.

57 Zimmermann, Kleinschmidt, supra note 49, p. 448 and literature quoted thereof - in context of non-applicability of $\S 830(2) 1$ BGB.
} 
victim". Paragraph (1) refers to a classical hunting-case scenario. Each activity is then regarded as a cause in respect to the likelihood (probability) that it may have caused the damage, and the tortfeasor has to pay that corresponding share ${ }^{58}$. In a case where the number of all the potential tortfeasors is unknown (for example in mass torts cases), the defendants should identify the other (potential) tortfeasors, which are not yet before the court. If they fail to do that, the court may apportion the loss between the known defendants in accordance with the likelihood that they caused the damage ${ }^{59}$. In turn para. (2) refers to DES-cases scenario. The proposition presented in Principles of European Tort Law refers to the market share liability test (or in other cases - a similar yardstick to attribute the loss). In a case where there is no basis to establish market shares of several tortfeasors with small market-share, their shares are presumed to be equal (Article 3:105 PETL) ${ }^{60}$.

Legislature in various European countries does not usually follow the proportionate liability pattern as proposed by PETL. An exception might be found in § 2925(2) of the Czech Civil Code 2012 for a specific type of cases, namely abnormally hazardous activities. It reads that "If circumstances clearly indicate that the operation has significantly increased the risk of damage, although it can be legitimately linked to other possible causes, a court shall order the operator to provide compensation for the damage to the extent that corresponds to the probability of the damage having been caused by the operation"61. This rule is however regarded as exceptional, and its scope of application is narrow ${ }^{62}$.

Proportional liability successfully developed in English case-law according to work-related diseases. It started from the crucial (and controversial ${ }^{63}$ ) judgment Fairchild v. Glenhaven Funeral Services Ltd [2002] ${ }^{64}$

\footnotetext{
58 European Group on Tort Law, supra note 14, p. 48.

59 Ibidem, p. 49.

$60 \quad$ Ibidem, p. 49.

61 Translation in: Infantino, Zervogianni, supra note 4.

62 See: ibidem.

63 For example, according to K. Oliphant, "the decision represents a bold but justifiable response to the problem of the «indeterminate defendant»" - K. Oliphant, England, [in:] B. Winiger, H. Koziol, B.A. Koch, R. Zimmermann (eds), Digest of European Tort Law, Vol. 1: Essential Cases on Natural Causation, Wien-New York 2007, p. 379; K. Oliphant, England, [in:] H. Koziol, B.C. Steinninger (eds), European Tort Law 2002, Wien 2003, p. 146. In contrast, J. Thomson asked "Can there be better examples [than Fairchild and Barker - KKL] of hard
} 
where three claimants had been unlawfully exposed to asbestos dust during their successive employment by several employers and contracted mesothelioma. It was scientifically not possible to establish whether the cancer resulted from exposure to a single asbestos fibre, a number of fibres or by cumulative exposure. Therefore the injury was an "indivisible" one, as it was impossible to determine in which employment period the cancer was triggered 65 . Importantly however, the uncertainty had to be scientific and not merely evidential66. The House of Lords ruled for the claimant and awarded compensation from the employers explaining (by majority opinion) that the tortfeasor's breach of duty had materially contributed to an increased risk of injury (contracting mesothelioma). Lord Rodger specified that "It is therefore essential not just that the defendant's conduct created a material risk of injury to a class of persons but that it actually created a material risk of injury to the claimant himself" and "that the defendant's conduct must have been capable of causing the claimant's injury". Therefore "the claimant must prove that his injury was caused by the eventuation of the kind of risk created by the defendant's wrongdoing (...). By contrast, the principle does not apply where the claimant has merely proved that his injury could have been caused by a number of different events, only one of which is the eventuation of the risk created by the defendant's wrongful act or omission". What is more, "the claimant

cases making bad law?" - J. Thomsom, Barker v. Corus: Fairchild Chickens Come Home to Roost, Edinburgh Law Review 2006, vol. 10, p. 426; similarily J. Morgan wrote that Fairchild "was a hard case that made bad law" - Morgan, supra note 32, p. 395.

64 [2002] UKHL 22.

65 See: M.A. Hogg, Re-Establishing Othodoxy in the Realm of Casuation, Edinburgh Law Review 2007, vol. 11, pp. 13-14.

66 See: Bagińska, supra note 5, pp. 148-149. The question of scientific uncertainty in the mesothelioma case was under consideration in a later case Sienkiewicz v. Greif and Knowsley Metropolitan Borough Council v. Willmore [2011] UKSC 10. In the fact of this case there was proof upon statistical data that the plaintiff's mesothelioma was in $85 \%$ probability caused by environmental exposure to asbestos (i.e. the factor for which no one bears liability) and not liable employee. Therefore on balance of probabilities upon the statistical proof it was established that defendant was not the cause of plaintiff's injury. UK Supreme Court held nevertheless employer's full liability. The Court claimed that defendant materially increased the risk of mesothelioma by $18 \%$, which was not de minimis, but enough to establish a causal connection in this case. The statistical data was regarded as not decisive, so the prerequisite of "scientific uncerainty" was met. It was explained that statistical data are not adequate in mesothelioma cases, because it is an indivisible damage and does not depend on the magnitude of exposure to asbestos. 
must prove that his injury was caused, if not by exactly the same agency as was involved in the defendant's wrongdoing, at least by an agency that operated in substantially the same way". Importantly, it was also said that the principle applies to situations where "the other possible source of the claimant's injury is a similar wrongful act or omission of another person" or where "the other possible source of the injury is a similar, but lawful, act or omission of the same defendant" ${ }^{\prime 6}$. In the Fairchild judgment the House of Lords did not indicate whether liability should be joint and several or individual and about the extent to which each defendant was to indemnify the claimant for damage ${ }^{68}$. Proportional liability was established in a later case Barker v. Corus UK Ltd [2006]69, which is said to be "the most important development in British causal jurisprudence in the last twenty years" 70 . In these three joint cases concerning again mesothelioma cancer contracted by workers, the House of Lords held employers liable in proportion to the magnitude of the risk of injury to which workers were exposed ${ }^{71}$. The criteria upon which damages were to be apportioned were left for the parties. According to Lord Hoffmann, they should be apportioned according to the defendant's contribution to the risk. He suggested that it might practically be: the time of exposure for which each defendant is responsible, the intensity of the exposure or the type of asbestos ${ }^{72}$. The House of Lords therefore reversed the Appellate Court decision holding the defendants jointly and severally liable for the whole indivisible injury. According to the understanding of the concept of causation after the Fairchild case, in Durham v. BAI (Run Off) Ltd [2012] $]^{73}$ the Supreme Court explained that Fairchild liability is for "causing mesothelioma"

\footnotetext{
67 Lord Rodger in Fairchild, para. 170.

68 See: Bagińska, supra note 5, p. 148. However according to M.A. Hogg in Fairchild "the material increase in risk principle was to be utilised to find the two employers jointly and severally liable for such an indivisible injury (...)" - Bagińska, supra note 65, p. 15.

69 UKHL 20, [2006] 2 A.C. 572 (HL).

70 Hogg, supra note 65, p. 15.

71 See: ibidem, p. 16. According to a recent case International Energy Group Ltd v. Zurich Insurance Plc UK [2015] UKSC 33; [2015] 2 W.L.R. 1471 (SC), when it comes to employer's recovery from insurer who insured employer only for certain period of time during which he employed victim with asbestos exposure (6 out of 27 years) UKSC ruled (in majority) that insurer is liable in full (but can claim a contribution from other insurers), and not pro rata.

72 Lord Hoffmann in Barker v. Corus, para. 48.

73 UKSC 14; [2012] 1 W.L.R. 867 (SC).
} 
and not for "increasing the risk of mesothelioma", however it is an "unconventional", "broad", and "weak" meaning of causation.

It needs to be recalled here, that the Barker case prompted the UK legislator to enact a new regulation in sec. 3 of the Compensation Act 2006 holding those liable for unlawful exposure to asbestos jointly and severally liable to the victim for his/her contracting mesothelioma. The application of those rules is however restricted first, only to mesothelioma cases (beyond them the rules of Fairchild/Barker are still applicable) ${ }^{74}$ and second, to territories to which the Compensation Act 2006 is in force ${ }^{75}$.

In contrast to the all-or-nothing approach, the arguments for holding defendants proportionally liable are explained in similar way to those already mentioned in favour of joint and several liability. It is then claimed that equity and policy reasons call for holding each defendant liable (even if the causal relation between exposure and disease has not been proved owing to scientific uncertainty) and is "heavily overweighed" by the injustice in not compensating a victim who has suffered from the materialisation of the risk at which each defendant wrongfully put him/her. As Lord Bingham in Fairchild explained: "such injustice as may be involved in imposing liability on a duty-breaking employer in these circumstances is heavily outweighed by the injustice of denying redress to a victim. Were the law otherwise, an employer exposing his employee to asbestos dust could obtain complete immunity against mesothelioma (but not asbestosis) claims by employing only those who had previously been exposed to excessive quantities of asbestos dust. Such a result would reflect no credit on the law"76. Referring to Lord Wilberforce's opinion in McGhee [1973]77 it was cited that "the employers should be liable for an injury, squarely within the risk which they created and that they, not the pursuer, should suffer the consequence of the impossibility, foreseeably

\footnotetext{
74 See: Oliphant, supra note 30, p. 154. Lord Mance (para. 27) and Lord Sumption (para. 179) in International Energy Group Ltd v. Zurich Insurance Plc UK [2015], UKSC 33. According to Lord Sumption "the Act left the common law intact, but carved an exception out of it for mesothelioma".

75 See: International Energy Group Ltd v. Zurich Insurance Plc UK [2015], UKSC 33.

76 Lord Bingham in Fairchild v. Glenhaven Funeral Services Ltd [2002] UKHL 22, [2003] 1 AC 32, para. 33.

$77 \quad$ McGhee [1973] 1 W.L.R. 1, para. 7.
} 
inherent in the nature of his injury, of segregating the precise consequence of their default".

Arguments for holding tortfeasors proportionately liable, instead of jointly and severally, were also presented extensively in comments on Principles of European Tort Law and by Lord Hoffmann in the Barker case.

In comments on Principles of European Tort Law the proportional liability approach was called "innovative", therefore it needed to be well reasoned. The starting point seems to be a good balance between the victim's and the liable person's interests. According to the Group's view, a tortfeasor should not be forced to compensate for a loss that was not caused by him, i.e. for the activity that does not even pass a condition sine qua non requirement ${ }^{78}$. On the other hand, it would be also inappropriate to leave the victim without compensation" ${ }^{79}$. The borderline between liability and non-liability is in many instances and cases rather a grey zone. (...) In that grey area, which probably covers a large number of day to day cases, the justification for establishing liability is almost as convincing as the opposite would have been. Moreover, coincidence (or bad luck), either on the side of the victim or of the tortfeasor, often play a considerable role. Seen from this angle, and depending on the merits of the case at hand, it might be counter-productive for the victim to opt for solidary liability. After all, if the court would take the view that solidary liability would be unfair in that specific case, it might feel reluctant to establish liability, as that would be the only feasible way to avoid the harshness of undesirable solidarity in that case" 80 .

In the circumstances of a particular case (Barker), those arguments are also reflected in Lord Hoffmann's opinion. According to his Lordship, joint and several liability is legitimate when a defendant caused harm, so there is no reason to reduce liability because another tortfeasor participated in causing it. On the contrary, "when liability is exceptionally imposed because you may have caused harm, the same considerations do not apply and fairness suggests that if more than one person may have been

\footnotetext{
78 European Group on Tort Law, supra note 14, p. 46.

79 Ibidem, p. 48.

80 Ibidem, pp. 46-47.
} 
responsible, liability should be divided according to the probability that one or other caused the harm"81. According to Lord Hoffmann the proportionate liability "would smooth the roughness of the justice which a rule of joint and several liability creates" and that wrongdoer "should not be liable for more than the damage which he caused and, since this is a case in which science can deal only in probabilities, the law should accept that position and attribute liability according to probabilities".

\section{FINAL REMARKS}

Neither of the three solutions to the problem of indeterminate defendant presented above is perfect. The all-or-nothing approach is hard and inevitably leads to an inequitable solution either on the side of a victim or of a potential tortfeasor. It was well observed, that the essence of this solution lies in standard and burden of proof in each jurisdiction ${ }^{82}$. Therefore the proper outcome seems to be the imposition of liability on possible tortfeasors. As stated above, in many countries a solution to the problem is found in the imposition of joint and several liability, which outcome is in fact a collective liability. The victim may be therefore naturally inclined to sue the tortfesor who is the most solvent. The bold proposition of proportional liability presented in Principles of European Tort Law seems to be then the better solution. Of course, there are certain threats, like that in scenario 1.2. it may urge the victim to start litigation against many defendants, however it is legitimate to claim that „it is insufficient justification to hold someone liable for a loss he cannot have caused"83.

81 Lord Hoffmann in Barker v. Corus, para. 43.

82 See: Infantino, Zervogianni, supra note 4.

83 European Group on Tort Law, supra note 14, p. 50. 
